\title{
DO TYPES OF ORGANIZATIONAL CULTURE CORRELATE WITH THE JOB SATISFACTION?: A STUDY ON EMPLOYEES' PERCEPTION
}

\author{
Apakah Tipe Budaya Organisasi Berhubungan dengan Kepuasan Kerja?: \\ Studi Tentang Persepsi Pegawai
}

\author{
Diajeng Puspa Arum Maharani ${ }^{1}$, *Firda Nadia Roshandi ${ }^{2}$ \\ ${ }_{1,2}$ Faculty of Public Health, Universitas Airlangga, Indonesia \\ ${ }^{\star}$ Correspondence: firda.nadia.roshandi-2015@fkm.unair.ac.id
}

\begin{abstract}
Background: The Orthopaedic and Traumatology Hospital had an increase in employee turnover of $1.39 \%$ from January to June 2012. It occurred due to high resignation and employee unsatisfaction. Thus, an organizational culture that consists of clan, hierarchy, market, and adhocracy becomes one of the determinant factors for employee turnover.

Aims: This study aims to analyze the correlation between organizational culture and the employees' job satisfaction.

Method: This study used descriptive quantitative with a cross-sectional design, and the data were analyzed with a correlation test. There were 52 employees as the data of this study. The instruments utilized were OCAI and JSS questionnaires.

Results: Market-type organization correlated significantly with job satisfaction. Organizational culture type, such as clan-type organization, adhocracy-type organization, and the hierarchy-type organization did not correlate significantly with job satisfaction. The majority of employees perceived that the Orthopedic and Traumatology Hospital adopts a hierarchy-type organization orienting to regulation and leadership. On the other hand, they expected the hospital to apply clan-type organizations that concerned about teamwork and ownership.

Conclusion: There is a correlation between the market-type organization and job satisfaction. Meanwhile, there is no correlation between the clan-type organization, adhocracy-type organization, hierarchy-type organization, and job satisfaction. The hospital should increase internal strength, such as teamwork, training, facilities, and policies that support work procedures and staff.
\end{abstract}

Keywords: market, adhocracy, clan, hierarchy, employees' job satisfaction.

ABSTRAK

Latar Belakang: Rumah Sakit Orthopedi dan Traumatologi mengalami peningkatan persentase pergantian pegawai sebesar 1,39\% pada periode Januari hingga Juni tahun 2012. Hal ini disebabkan karena tingginya jumlah pegawai yang keluar dan faktor ketidakpuasan kerja. Salah satu faktor yang mempengaruhi pergantian pegawai adalah budaya organisasi, antara lain klan, hirarki, adokrasi, dan pasar.

Tujuan: Penelitian ini menganalisis hubungan antara budaya organisasi dengan kepuasan kerja pegawai.

Metode: Penelitian ini menggunakan teknik statistik deskriptif, korelasi dengan desain cross sectional. Sampel dalam penelitian ini adalah karyawan aktif yang berjumlah 52 orang. Instrumen yang digunakan adalah kuesioner OCAI dan JSS.

Hasil: Budaya organisasi tipe pasar berhubungan secara signifikan dengan kepuasan kerja. Budaya organisasi tipe klan, adokrasi dan hirarki tidak berhubungan secara signifikan dengan kepuasan kerja. Mayoritas pegawai menganggap bahwa Rumah Sakit Orthopedi dan Traumatologi mengadopsi tipe hirarki yang berorientasi pada aturan dan kepemimpinan. Sedangkan, tipe budaya organisasi yang diharapkan oleh pegawai adalah klan yang mengacu pada kerja tim dan kekeluargaan.

Kesimpulan: Terdapat hubungan antara budaya organisasi tipe pasar dengan kepuasan kerja, sedangkan pada budaya organisasi tipe klan, adokrasi dan hirarki tidak terdapat hubungan secara signifikan. Rumah Sakit diharapkan dapat meningkatkan kekuatan internal, dalam kerja tim, pelatihan, fasilitas dan kebijakan yang mendukung prosedur kerja serta staf rumah sakit.

Kata kunci: adokrasi, hirarki, klan, pasar, kepuasan kerja pegawai. 


\section{INTRODUCTION}

Human resource is one of the integral parts of the organization or company. Besides, human resource has a significant role in the organization or company. In the globalization era, every organization or company has a desire to improve and develop their organization or company performance using the way that is arranged in the program. Increasing or developing either in the company or organization can be started by improving employees' performance. Employee is considered as one of the important assets in the organization or the company. The organization or company requires employees with high performance, so they can work well and fast. There are many factors that relate to the employee's performance improvement, i.e., individual or the organization.

The human resource of every organization or company has a different quality. It also occurs in developed countries that have a higher quality of human resources than in developing countries. Human resources are the most crucial assets of organizations, both in large and small scales, as they are the sources that direct organizations, as well as maintain and develop organizations in various demands of communities and time (Susilo and Muhid, 2015).

Hence, the human resource relates directly with the function of the organization or company that organizes several aspects, such as the organization or company development, compensation, salary, employees' training, employees' administration, and employees' communication. The human resource management duty is to manage the employees as the human element with the potential that they have so that they can obtain satisfying results and satisfactory for the organization and company (Gibson et al., 2011).

Sari and Susilo (2018) define job satisfaction as a representation of employees' attitudes and assessments regarding their works and the fulfillment of expectations. The more aspect of the job that fits with the desire or the individual aspect, the higher job satisfaction tends to be. Job satisfaction reflects someone's feeling of his or her job. People will be satisfied when there is no discrepancy between what they expect and reality.

Although there is a difference between expectation and reality, it makes the employees feel satisfied since the difference is a positive aspect. However, if the difference is a negative aspect, it decreases the employees' satisfaction. It is reflected in the employees' positive behavior towards the job. In addition, any conditions that are faced by the employees in the work environment has a different satisfaction standard according to the employees' values. For many people, one of the aims they work is to obtain job satisfaction. Job satisfaction will be obtained if the work can motivate workers to achieve good performance.
The discussion of the employees' job satisfaction cannot be separated from the factors that influence job satisfaction. Therefore, job satisfaction is always consistent. The organization or company always pays attention to the environment because the work environment includes colleagues, leaders, job situations, and the other aspects that can affect employees at work.

The organization or company achievement is influenced by the employees' performance. Every organization or company will attempt to improve their employees' performance. The organization or company improve the employees' performance, such as realizing the employees' job satisfaction through organizational culture. The organization or company always expects that the employees' performance will always satisfy. To improve the employees' contribution to the organization or company, numerous empowerment programs require to be implemented. The empowerment is performed by the organization or company that focuses on providing the products and services.

A recent study by Gibson et al. (2011) stated that there are three factors that impact employees' performance. The first factors are individual factors, such as creativity, family background, ability, work experience, social life, and demography. The second factors are role, perception, motivation, and job satisfaction. The third factors are psychologist factors, such as leadership, organizational structure, work design, and reward system. In correlation to psychological factors, organizational culture affects employees' job satisfaction.

There are many types of research concerning job satisfaction and the correlation with organizational culture. A study conducted by Tumbelaka, Alhabsji, and Nirman (2016) suggests that the influence of organizational culture on job satisfaction is positive. It could be proven from the coefficient's result of 0.726 . It indicates that the stronger organizational culture will increase employees' job satisfaction in the company. Another research conducted by Ali and Wijaya (2018) stated that organizational culture affects satisfaction and provides a positive effect on the employees.

The employees are given more authority and responsibility to make a decision. Therefore, communication or exchanging information and knowledge between the manager and the employees is necessary so that they can really understand their duties and give a real contribution to the organization or company achievement. The organizational culture is a value system obtained and developed by the basic philosophy and habit of the organization and leader. The organizational culture is an instrument of primary competitive advantage because it can support and overcome the environmental challenge appropriately.

The organizational culture provides a positive impact and affects the motivation and the employees' performance. It is an essential aspect for the organization or company because it includes 
the behavior norms that are obeyed by the members.

The leader's effectiveness is affected by the employees' characteristics and related to the communication process between the manager and employees. The leaders are failed when they cannot motivate, encourage, satisfy the employees of the job or certain environment. The leaders have to encourage their employees in order to anticipate every challenge and chance in the job.

Although the empowerment and organizational culture program have been carried out, there are still problems related to the human resource in the organization. Orthopedic and Traumatology Hospital was one of the hospitals that were established in 2010. Orthopedic and Traumatology Hospital still has obstacles, one of which is the human resource asset.

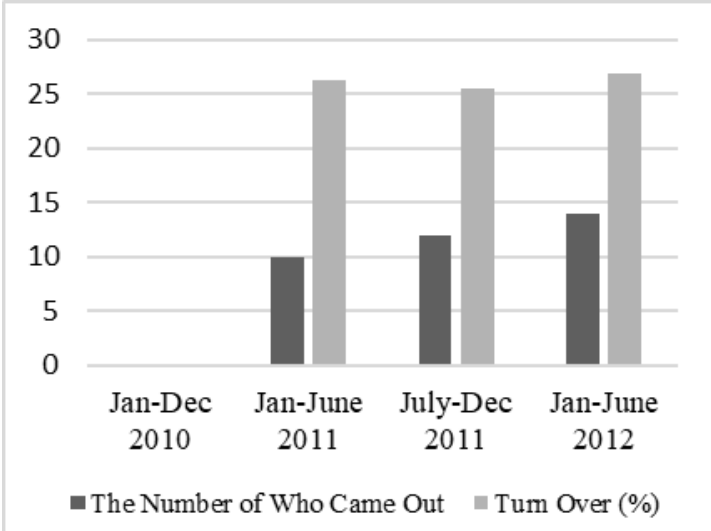

Figure 1. The Number of Employee Turnover during 2010-2012.

The turnover rate from January to June 2012 period increased by $1.39 \%$ than the previous period. The increase in turnover rate signified that the intention to leave Orthopedic and Traumatology Hospital was quite high. The intention to leave was the result of employees' dissatisfaction. Dissatisfied employees had a significant intensity of perceptions regarding organizational culture. This study analyzed the correlation between employees' perceptions and employees' job satisfaction in Orthopedic and Traumatology Hospital.

\section{METHOD}

This study was a descriptive quantitative. The data were analyzed employing a correlation test. The research conducted from December 2012 to August 2013.

The data population was 68 employees at Orthopaedic and Traumatology Hospital that were actively working until June 2013. The samples were 52 employees of Orthopaedic and Traumatology Hospitals. The hospital was selected because of the high turnover rate in the hospital that may influence job satisfaction.

The data collection for primary data were obtained from the questionnaire. The questionnaire consisted of two types of instruments, i.e., OCAI (Organizational Culture Assessment) and JSS (Job Satisfaction Survey). OCAI assessed organizational culture perception specifically at Orthopedic and Traumatology Hospital among the employees, while JSS measured job satisfaction. The results from the questionnaires were changed into interval data and analyzed using statistical analysis software to identify the correlation of each variable.

\section{RESULTS AND DISCUSSION}

\section{The Characteristics of the Respondents Based on Sex and Work Unit}

The majority of respondents were female, which amounted to $67.31 \%$ or 35 employees. However, the male respondents reached $32.69 \%$ or 17 males. The respondents consisted of 16 work units in the hospital, i.e., outpatient, inpatient, housekeeping, finance, pharmacy, laboratory, human resource, IBS, ADM medical, IPS medical, IPS non-medical, general, front office, radiology, physiotherapist, and medical record.

The data collection was carried out for 2 weeks using questionnaires distributed to the respondents. The distribution of questionnaires was adjusted to the respondents' shift schedule. The data retrieval was conducted after the respondents had completed their works in the hospital or by waiting for the respondents' free time.

\section{The Perception of Organizational Culture}

To identify the perception and respondents' aspiration about the organizational culture, it could be performed by using Organizational Culture Instrument (OCAI). According to the instruments, there were four types of organizational cultures, such as hierarchy-type organization, market-type organization, clan-type organization, and adhocracy-type organization which had different characteristics.

The first type was clan. This type of organization emphasized more on teamwork and involved in the program and commitment with organization or the company. The employees percieved that environment was well-managed by developing employees' skills and teamwork.

The second type was the adhocracy. This type had numerous goals, such as encouraging flexibility, creativity and adapting to the unstable situation. The adhocracy focused on external and differentiation. In this case, the environment was creative entrepreneurship. Every aspect of human resources should bravely take a risk. The leader was also oriented on the risk, vision and innovation. Besides, the leader who had different thoughts would make the organization's members reached their goals. Freedom and initiative were highly appreciated. However, the adhocracy-type organization could change quickly depended on the situation.

The third type was market. This type had minor similarities to the hierarchy type. The 
similarities were on the control and stability aspects which were carried out by the organization. However, the difference was in the focus aspect. This type was focused on the external aspect which also focused on the correlation and transaction with the other parties, such as supplier, contractor, customer, consultant, regulator, and legislator. The organization used in this type was emphasized on wisdom and flexibility rather than the organization's integration and stability. This type also had a friendly and open work environment that facilitated the people to interact with each other. The leader of this type was considered as both parents and mentors as well that would manage the organization like an extended family.

The last type was the hierarchy. This type was formal and structured. In this type, the leader was required to be a coordinator and manager who had a mindset and efficiency approach. The type of organization was more concerned about standardization, standard, and the assertive structure of the decision or authority making the process, and control. The long term orientation of the type of organization was emphasized on the operation, stability, and efficient performance.

The measurement of organizational culture was used to identify how far it would be understood and utilized as work guidance for all employees of the organization or company. The majority of the employees perceived that the Orthopedic and Traumatology Hospital was a hierarchy-type organization with an average score reached 26.65. This result had a tendency to the quadrant II, i.e., internal focus.

Hierarchy-type organizations tended to be quadrant II, which is the hospital focused on the internal strength according to the authority and policy that was made by the hospital's leader. It emphasized formal coordination, centralized decision making, and authority. This culture emphasized stability. This hierarchical culture was described as hard, precise, unchanging, neat and clean (Parashakti, Rizki, and Saragih, 2016).

If the hospital adopted a hierarchical type, the leader would tend to work efficiently and regularly. The leader would organize the employees to achieve the goals of the hospital. Excellent hospital management offered a comfortable feeling to the employees so that they believed that their job did not give excessive workload.

The study conducted by Saleem, Ashraf, and Mir (2018) stated that the market was the dominant culture in their research. The differences in the study results were presumably due to the differences in the type of agencies studied. A hospital with the hierarchical type was more structured and controlled than the others. The goals of the hospital as high-quality health services for the community could be achieved if the employees could discipline and obeyed the hospital's regulations. Meanwhile, the organizations in the banking sector were dominated by the market-type organization. Generally, banks required to compete in order to gain lots of profits, thus, market-type organization is the most suitable type. The employees in this sector had a various targets to achieve during a certain period of time. This aspect was a primary attribute of the market-type organization's culture.

Management implementation created a dynamic correlation among the employees in corporation. In this case, all matters were performed by employees to keep away the conflict and complete the jobs well. Besides, it also encouraged a stable situation. A adherence and discipline were the main keys of Orthopedic and Traumatology Hospital's sustainability process. The hospital created a regulation that had to be obeyed by the employees so that if a violation occured, they would be sanctioned. The Orthopedic and Traumatology Hospital's employees must have good behavior to the hospital's managers, colleagues, visitors, and patients, because it reflected the hospital's moral.

Orthopedic and Traumatology Hospital emphasized the discipline as an important aspect to reach stability and manage a situation. The hospital made policies and regulations that referred to the efficient results with a stable and controlled situation. The stability achievement and managing condition were carried out by the leader's capability to regulate the subordinate as well as the cooperation between the obeyed and disciplined employees on the hospital's policies and regulations. In this context, the policy implementation of the hospital required an explanation that can be understood by the employees. Hence, there was no confusion and did not create an uncomfortable feeling to the employees.

The employees mostly expected the Orthopedic and Traumatology Hospital to adopt clan-type organization with the average score of 27.50. The results tended to quadrant II, i.e.,internal focus. The employees who perceived the hospital as clan-type organizationwere assumed as the hospital's members.

Clan-type organization allowed people to share considerably. Extensive participation, teamwork, consensus, decentralized decisionmaking and loyalty were all parts of this clan's culture. Clan-type organization always adhered to loyalty and tradition (Parashakti, Rizki and Saragih, 2016).

On the other hand, the expected leader was the reliable leader to train the subordinates with an attitude as a mentor without any coercion. Besides, a leader was expected as a facilitator between the employees and hospital. If employees expressed their aspirations which was considered as loyality or responsiblity, their aspirations could be delivered appropriately. The employees expected Orthopedic and Traumatology Hospital could give them training to improve their performance expectations to the 
hospital and the cooperation that will increase the employees' performances.

The employees' loyalty increased when they appreciated and respected each other. The feeling also gave comfort for the employees to stay in the hospital. Therefore, it could decrease the employees' turnover level because they were satisfied. Besides the loyalty, the other important thing was trust. Trust was not only possessed by the employees but also the leader. Besides, the leader had to appreciate the employees so that they could implement it to the colleagues. All employees of Orthopedic and Traumatology required to cooperate well as a team and to support each other to achieve a great performance.

\section{Job Satisfaction}

Noe et al. (2008) define job satisfaction as a feeling that is generated from the perception that the job had fulfilled, or allow the employees can satisfy the work's important values. In calculating the Orthopedic and Traumatology Hospital's employees individually based on the job satisfaction aspect, it is obtained the following results.

The Orthopedic and Traumatology Hospital's employees had the highest satisfaction on the job characteristic aspects. The second aspect that had the highest satisfaction was supervision, then followed by colleagues, appreciation, rewards and promotions, work benefits and communication. Meanwhile, the lowest aspect was the operational procedure.

The highest aspect was job characteristics for the Orthopedic and Traumatology Hospital's employees that had score 265.500 in the highest job satisfaction. It indicated that the employees felt highly satisfied with their jobs in the hospital. They were responsible for their duties that were appropriate with their capabilities, therefore, they did not feel difficult to work in the hospital. It related to the recruitment process and employee training. The employee training provided an important role to facilitate the employees in order to have high capabilities to do their duties. Besides, it was also intended to improve hospital quality.

In the questionnaire, there were 9 aspects, such as reward, promotion, supervision, work benefit, appreciation, operational procedure, colleagues, job characteristics, and communication. The lowest aspect was the operational procedure for the Orthopedic and Traumatology Hospital with 202.500 scores. It indicated that the employees' satisfaction with the procedure operates in the hospital was lower than the other job satisfaction aspects. The operational procedure was a policy and regulation applied by the hospital. In this context, from the employees' job perception, it helped to solve the employees' duties in a difficult situation. However, it also could be an obstacle for the employees to do their duties effectively and efficiently. The hospital required to provide a solution toward the operational procedure which could damage the employees' job processes and results. In case there was no solution given, there would be employees who were dissatisfied with their duties.

Table 1. The Employees' Job Satisfaction.

\begin{tabular}{lccc}
\hline $\begin{array}{l}\text { Level of Job } \\
\text { Satisfaction }\end{array}$ & Range & $\mathbf{N}$ & $\%$ \\
\hline Low & $36-81$ & 0 & 0 \\
\hline Medium & $82-126$ & 1 & 1.92 \\
\hline High & $127-171$ & 41 & 78.85 \\
\hline Very High & $172-216$ & 10 & 19.23 \\
\hline Total & & 52 & 100 \\
\hline
\end{tabular}

Table 2. The Aspects of Job Satisfaction.

\begin{tabular}{lccc}
\hline \multicolumn{1}{c}{ Aspects } & $\begin{array}{c}\text { Standard } \\
\text { Deviation }\end{array}$ & Mean & $\boldsymbol{\Sigma}$ \\
\hline Reward & 0.816 & 4.163 & 216.500 \\
\hline Promotion & 0.669 & 4.163 & 216.500 \\
\hline Supervision & 0.785 & 4.601 & 239.250 \\
\hline Work Benefit & 0.630 & 4.096 & 213.000 \\
\hline Appreciation & 0.943 & 4.221 & 219.500 \\
\hline $\begin{array}{l}\text { Operational } \\
\text { procedure }\end{array}$ & 0.759 & 3.894 & 202.500 \\
\hline $\begin{array}{l}\text { Colleagues } \\
\text { Job }\end{array}$ & 0.709 & 4.520 & 235.000 \\
\hline Characteristic & 0.654 & 5.106 & 265.500 \\
\hline Communication & 0.640 & 4.096 & 213.000 \\
\hline
\end{tabular}

\section{The Influence of Organizational Culture toward Job Satisfaction}

Noe et al. (2008) explained that employees with the highest job satisfaction will have a positive feeling for the job. Nevertheless, employees with low job satisfaction will get a negative feeling.

Figure 2 denoted that the organization and company culture influenced job satisfaction. This research also revealed that the organization culture influences job satisfaction. The organization had a correlation with a group atmosphere. The employees would be comfortable with the positive group atmosphere, and it would be either positive or negative depending on the employees' job satisfaction.

It was congruent with the research conducted by Nugraha and Rozak (2017), which stated that the influence of organizational culture variable towards job satisfaction reaches $28.3 \%$. Thus, the organizational culture variable has a positive influence which is significant to increase job satisfaction. It means if the organizational culture improves, then job satisfaction will also increase.

In terms of organizational culture, there were the organization or company types, such as clantype organization, market-type organization, hierarchy-type organization, and adhocracy-type organization. Those types were studied to identify their correlation with job satisfaction. 
The Correlation between Clan-Type Organization toward Job Satisfaction

A clan is a kind of organizational culture that resembles a family system, and it refers to the cooperation, employees' participation program, and commitment that had by every employee (Cameron and Quinn, 2011). There are 3 assumptions to the organizational culture clan. First, the environment can be organized with cooperation and enhancement of the employees' competencies. Second, customers are partners, and the last is the organization or company as the employees' environment to grow.

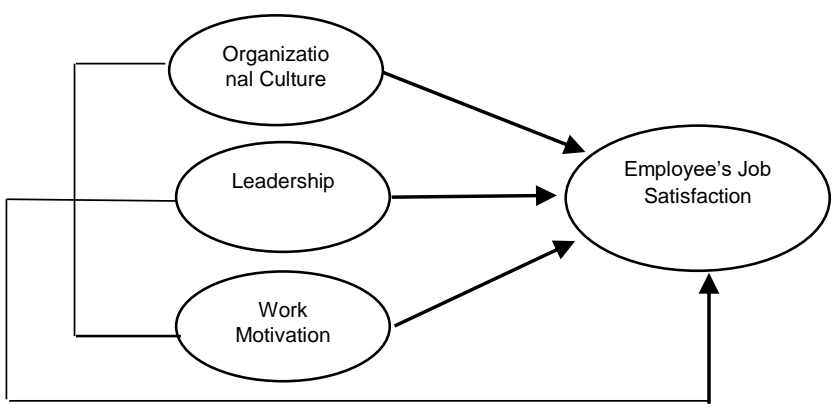

Source: Mawei, Nelwan, and Uhing (2014) Figure 2. The Regression Model of the Organizational Culture Influences toward Job Satisfaction.

According to the research conducted, clan type had a high correlation value to the job satisfaction that reached $R=0.254$. The correlation between organizational culture types and job satisfaction was positive, yet it was insignificant because of $p$-value $>0.01$. A positive correlation of the organizational culture clan type and job satisfaction indicated that both variables had the same objectives. The employees would be highly satisfied if the clan situation increased in the hospital. The insignificant value of clan type to job satisfaction indicated that there was no correlation between the two variables.

\section{The Correlation between Market-Type Organization toward Job Satisfaction}

Market type concerns with the organization or company that orients to the external factors, for instance, a transaction with the outside group such as suppliers, customers, contractors, licenses, unions, and regulators (Cameron and Quinn, 2011). The market emphasizes the mechanism of the market economy, dynamic competition, and money exchange by focusing on a profitable transaction.

Based on the research conducted, the correlation value of market-type organization with job satisfaction amounted to $\mathrm{R}=0.313$ which means negative yet significant with a $p$-value $<0.01$. The negative correlation between market type and job satisfaction suggested that both variable correlations did not have the same aims. The significant value of the market with job satisfaction indicated that there was a correlation between the two variables.

To conclude, the higher the market-type value, the lower the job satisfaction value would be. This research was similar to the previous research that had been conducted. According to Cameron and Quinn (2011), there are four of the organizational culture types that affect job satisfaction, one of which is market.

Market type commonly has an unstable characteristic because it is affected by external factors, such as consumers, and competing organization or company interests (Rangkuti, 2008). The characteristics that influence the employees of Orthopedic and Traumatology Hospital to have the lowest expectation of market type are dominant. In this case, it affects the employees' job satisfaction. Regarding the organization or company that focused on the external factor, the employees felt that they were not suitable for the organization or company, which eventually led to the employees' dissatisfaction.

\section{The Correlation between Hierarchy-Type Organization toward Job Satisfaction}

The culture concerns the organization or company that prioritizes the policies and structures in the workplace. The policies regulate the activity of every employee and require an effective leader to coordinate and organize the employees (Cameron and Quinn, 2011). The hierarchy type concerns the efficient and stable organization or company implementation. The policies and rules are the components merged in the hospital.

Based on the research, the hierarchy type had a correlation value that was $R=0.169$. The correlation between the hierarchy type and job satisfaction was positive. However, it was not significant because of $p$-value $>0.01$. The positive correlation between the hierarchy type and job satisfaction indicated that the two variables were in the same aims. The significant hierarchy value toward job satisfaction signified that there was no correlation between the two variables. In this context, it proved that if the hierarchy type increased, job satisfaction would increase as well.

In Fatima's research (2016), the results of the study concerning the influence between hierarchy and job satisfaction were negative and significant. Their works were illustrated by the results with the value of $\mathrm{t}=-4.777$ which was significant at the levels of $90 \%, 95 \%$, and $99 \%$. A negative value meant that if the hierarchy type increased, job satisfaction would decrease. The difference in the results of Fatima's research was caused by the type of questionnaire used. In Fatima's research utilized a self-administrated questionnaire, while this study used OCAI and JSS questionnaire. Besides, the samples used were also different. Those matters were likely to be the causes of different results. 
The dominant organizational culture type was hierarchy so that the employees were satisfied to work in Orthopedic and Traumatology Hospital. Nevertheless, the situation would be better if the clan type became the dominant organization and company because the employees expected clan type. It was in the quadrant II that focused on the internal focus. The employees needed to increase the hospital's internal aspects both in the employees' capabilities and facilities, and the work policies.

\section{The Correlation between Adhocracy-Type Organization toward Job Satisfaction}

Adhocracy is a kind of organizational culture that emphasizes innovation and successful research initiatives (Cameron and Quinn, 2011). The organization or company emphasizes on new product developments and services, and preparation for the future. The main duty of management is to support entrepreneurship, creativity, and useful activities to improve the hospital's innovation.

Based on the research, the adhocracy type had a high correlation value with the job satisfaction which was $R=0.181$. The correlation of adhocracy type with job satisfaction was negative and it was not significant because of $p$-value $>0.01$. The negative correlation on the adhocracy with job satisfaction indicated that the correlation between the two variables was dissimilar. The significant adhocracy type value with job satisfaction indicated that the two variables were not related. In this case, it stated if the adhocracy type increased, the employees' job satisfaction would decrease.

Fatima's research (2016) explained the results of the study that the influence between hierarchy and job satisfaction was positive and significant. The study was illustrated by the results with the value of $t=4.663$ which was significant at the levels of $90 \%, 95 \%$, and $99 \%$. A negative value meant that if the hierarchy type increased, job satisfaction would also improve. The differences in the results of Fatima's research were caused by the different types of organizational culture and job satisfaction levels. The dimensions of the organizational culture variable used were different. Fatima's research was divided into six key dimensions, i.e., dominant characteristics, organization leadership, employee management, the bond which held the organization together, the strategic criteria of organization, and success.

Table 3. Mean, Standard Deviation, and Zero Correlation of Perception of Organizational Culture and Job Satisfaction.

\begin{tabular}{lcccrrrr}
\hline \multicolumn{1}{c}{ Variable } & Mean & SD & Clan & Adhocracy & Market & Hierarchy & $\begin{array}{c}\text { Job } \\
\text { Satisfaction }\end{array}$ \\
\hline Clan & 25.305 & 4.694 & 1.000 & & & & \\
\hline Adhocracy & 22.932 & 2.601 & 0.182 & 1.000 & & & \\
\hline Market & 24.616 & 3.790 & -0.664 & -0.084 & 1.000 & & \\
\hline Hierarchy & 26.651 & 4.323 & -0.409 & -0.585 & -0.106 & 1.000 & 1.000 \\
\hline Job Satisfaction & 3.179 & 0.423 & 0.254 & -0.181 & $-0.313^{*}$ & 0.169 & \\
\hline${ }^{*}$ The significant correlation on the 0.05 level (2-tailed) & & & & &
\end{tabular}

The characteristics of an adhocracy type that focused on entrepreneurship and improved creativity could give an influence on the job satisfaction of the Orthopedic and Traumatology Hospital. The employees felt satisfied when the hospital was capable to increase the employees' creativity by conducting an education seminar. However, the employees did not concern about entrepreneurship, thus, the hospital would be better to focus on the employees' teamwork internal strength.

\section{CONCLUSION}

To sum up, the organizational culture affects job satisfaction. Nevertheless, not all types of organizational culture have a correlation with job satisfaction. The organizational culture type that influences significantly to job satisfaction is the market with a negative correlation. In this case, the higher the market type value, then the lower job satisfaction will be. The results of the clan, adhocracy, and hierarchy types are insignificant. It indicates that there are several types that do not have a correlation to job satisfaction.
Clan-type organization and hierarchy-type organization have a positive correlation with the job satisfaction variable. For the high culture of clan or hierarchy type, the employees' job satisfaction will increase. On the other hand, the adhocracy type has a negative correlation towards employees' job satisfaction. Hence, it indicates that high adhocracy type causes the decrease of employees' job satisfaction.

The organizational culture type in Orthopedic and Traumatology Hospital classifies as hierarchy that concerns the rules-oriented and leadership. Nevertheless, the culture of the organization or company that is expected by Orthopedic and Traumatology Hospital's employees is a clan which concerns to the teamwork and a family atmosphere. Hence, it causes a discrepancy between the expectation and the organizational culture type of the Orthopedic and Traumatology Hospital. The level of the employees' job satisfaction is at a high level with the employees who have the suitability with their current jobs, yet it is hindered by the implementation of the operational procedure. Based on the study result, it is suggested that Orthopedic and Traumatology Hospital should encourage 
employees to give their aspirations and provide them trainings to improve their skills.

\section{CONFLICT OF INTEREST}

The authors state that there is no conflict of interest in this article.

\section{REFERENCES}

Ali, K. and Wijaya, D. A. (2018) 'Analisis Pengaruh Budaya Organisasi dan Gaya Kepemimpinan Terhadap Kepuasan Kerja Untuk Meningkatkan Kinerja Karyawan di Rumah Sakit Muhammadiyah Metro', Jurnal IImiah FE-UMM, 12(2), pp. 7-15.

Cameron, K. S. and Quinn, R. E. (2011) 'An Introduction to changing organisational culture: Based on the competing values framework', in Diagnosing and chaning organisational culture. 3rd editio. New Jersey: John Wiley \& Sons.

Fatima, M. (2016) 'The Impact of Organizational Culture Types on the Job Satisfaction of Employees', Journal of Management and Business, 3(1), pp. 13-32. doi: 10.30537/sijmb.v3i1.135.

Gibson, J. L. et al. (2011) Organizations - Behavior, Structurem Processes. 14th edn. New York: McGraw-Hill Education.

Mawei, A. C., Nelwan, O. and Uhing, Y. (2014) 'Kepemimpinan, Penempatan Kerja dan Kompensasi Pengaruhnya Terhadap Kepuasan Kerja Pada PT. Bank BNI (Persero), Tbk. KCU Manado', Jurnal EMBA, 2(2), pp. 944-954.

Noe, R. A. et al. (2008) Human Resource Management: Gaining a competitive advantage. 8th edn. New York: McGraw Hill.

Nugraha, R. and Rozak, D. A. (2017) 'Pengaruh Budaya Organisasi dan Pengembangan Karir Terhadap Kepuasan Kerja Karyawan: Studi Persepsional Pada Karyawan PT. Bank Bukopin Cabang Tasikmalaya', Journal of Management Review, 1(1), pp. 25-31.

Parashakti, R. D., Rizki, M. and Saragih, L. (2016) 'Pengaruh Kepemimpinan Transformasional dan Budaya Organisasi Terhadap Perilaku Inovatif Karyawan (Studi Kasus di PT. Bank Danamon Indonesia)', Jurnal Manajemen Teori dan Terapan, 9(2), pp. 81-96. doi: 10.20473/jmtt.v9i2.3015.

Rangkuti, F. (2008) The Power of Brands. 3rd ed. Jakarta: Gramedia Pustaka Utama.

Saleem, M., Ashraf, A. and Mir, A. R. (2018) 'Influence Of Organizational Culture On Job Satisfaction In Banking Sector Of Pakistan', Journal of Research in Business and Management, 6(2), pp. 28-46.

Sari, O. R. and Susilo, H. (2018) 'Organizational Citizenship Behavior Sebagai Variabel Intervening (Studi pada Karyawan PTPN X Unit Usaha Pabrik Gula Modjopanggoong Tulungagung)', Jurnal Administrasi Bisnis, 64(1), pp. 28-35.

Susilo, S. and Muhid, A. (2015) 'Kepemimpinan Transformasional, Kepuasan Kerja dan
Komitmen Organisasi', Persona: Jurnal Psikologi Indonesia, 4(3), pp. 304-313.

Tumbelaka, S. S. X., Alhabsji, T. and Nimran, U. (2016) 'Pengaruh Budaya Organisasi Terhadap Kepuasan Kerja, Komitmen Organisasional dan Intention to Leave (Studi pada Karyawan PT. Bitung Mina Utama)', Jurnal Bisnis dan Manajemen, 3(1), pp. 94108. 